\title{
Water demand and flows in the São Francisco River Basin (Brazil) with increased irrigation
}

\author{
M.P. Maneta ${ }^{\text {a,* }}$, M. Torres ${ }^{\text {b }}$, W.W. Wallender ${ }^{\text {a }}$, S. Vosti ${ }^{b}$, M. Kirby ${ }^{c}$, L.H. Bassoi ${ }^{\text {d }}$, L.N. Rodrigues ${ }^{\text {e }}$ \\ a Department of Land, Air and Water Resources, University of California, Davis, One Shields Avenue, 95616, Davis, CA, United States \\ ${ }^{\mathrm{b}}$ Department of Agricultural Resource Economics, University of California, Davis, One Shields Avenue, 95616, Davis, CA, United States \\ ' CSIRO Land and Water, GPO Box 1666, Canberra, ACT 2601, Australia \\ dEmbrapa Semiárido, BR 428, km 152, 56302-970 Petrolina, PE, Brazil

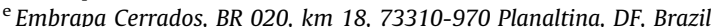

\section{A R T I C L E I N F O}

Article history:

Received 23 September 2008

Accepted 8 March 2009

Available online 15 April 2009

\section{Keywords:}

Water management

Large basin modeling

Water budget

Monte Carlo simulations

\begin{abstract}
A B S T R A C T
Most activities that support economic growth in the São Francisco River Basin (Brazil) need water. Allocation of the water resources to each competing use needs quantification in order to develop an integrated water management plan. Irrigation agriculture is the largest water consuming activity in the basin. It has produced large economic and social advancements in the region and has potential for further development. The local development agency in the São Francisco River has projected an increase of more than 500,000 ha in irrigation developments distributed within the basin.

Water requirements of the projected irrigation expansions and their effects on river flow were quantified. A semi-distributed model was constructed to simulate the water balance in 16 watersheds within the basin. The watersheds were hydrologically characterized by the average precipitation, atmospheric demand and runoff as well as their variability. Water requirements for increased irrigated agriculture were calculated using an agronomic mass balance. A Monte Carlo procedure generated the variability of irrigation requirements and resulting decreased river flows from the multidimensional probability distribution of the hydrologic variables of each watershed.

Irrigation requirements were found to be more variable during the wet season because of weather variability. In contrast to what might be expected, in drier years, irrigation requirements were often larger during the wet season than in the dry season because the cropped area is largest in the wet months and variability of precipitation is greater. Increased irrigation shifted downward the distribution of river flows but not enough to affect other strategic water uses such as hydropower. Further irrigation expansion may be limited by wet season flows.
\end{abstract}

๑) 2009 Elsevier B.V. All rights reserved.

\section{Introduction}

The São Francisco River has the largest basin fully contained within Brazil. It is located in the northeast part of the country covering about $630,000 \mathrm{~km}^{2}$. The river flows south to north along $2860 \mathrm{~km}$, covering diverse climatic regions. The population living within the territory drained by the river is about 13 million, with a large percentage living in the southern part and especially around the Belo Horizonte metropolitan area.

Due to its strategic importance, the São Francisco River Basin has been a focus in political debate. Not only because of its importance as a main route of transportation and communication between the coast and the interior, its hydropower potentials and its potential for irrigation but also because of the dangers posed by

\footnotetext{
* Corresponding author. Tel.: +1 530752 7415; fax: +1 5307525262

E-mail address: mpmaneta@ucdavis.edu (M.P. Maneta).
}

floods, droughts or those derived from environmental degradation, proper management of the basin is necessary. However, most of the actions taken in the past have focused on single specific sectors. The partial management of the basin may have had significant negative impacts on other water users because integrated management was inadequate in terms of harmonizing water demand with the potential supplies (Romano and Cadavid Garcia, 1999). Only from 1997 a federal law provides a legal framework for integrated management under the control of the National Water Agency of Brazil (ANA) and a Commission for the São Francisco River Basin that includes the participation of the public sector at federal, state and municipal levels as well as a wide range of water users and civil organizations (Braga and Lotufo, 2008).

Within the basin, irrigation has been seen as one of the greatest opportunities to foster economic and social development, especially in the semiarid northeast. According to the local development agency in the São Francisco River (CODEVASF), from the 1960s to 1975 the irrigated area has increased steadily at about 
5200 ha per year and ramped up in the 1980s, when large irrigation projects in the Northeast increased the rate of irrigation expansion to an average of 10,500 ha per year (CODEVASF, 1996; Romano and Cadavid Garcia, 1999). With increased irrigation, the amount of land suitable for irrigation is about $45 \%$ of the total area and this far exceeds the amount of available water (CODEVASF, 1994). Thus any expansion of the irrigated areas must be done within the context of an integrated management plan to prevent conflicts with other water uses. Furthermore, the expansion of irrigation has been done without a timely increase in support services and proper research and development to optimize agricultural activity (Romano and Cadavid Garcia, 1999). There are still a number of projects that intend the expansion of agriculture in the upper and middle section of the basin, supported by improved technical and administrative guidelines that would maximize economic and social advancement while minimizing environmental and economic risks. Those projected expansions of irrigated agriculture are grouped in six clearly defined development regions. The hubs are target areas for investment and policy action that are already significantly developed in terms of irrigation infrastructure, so further investments will produce rapid returns, increase the production for international markets and hopefully will boost development in neighbor areas. The decennial plan for water resource management in the São Francisco Basin includes the expansion of irrigated agriculture in more than 550,000 ha (ANA/ GEF/PNUMA/OEA, 2004), which is expected to cause conflicts with other competing water uses of strategic importance such as hydropower generation in the lower São Francisco River.

The objective of this study is to evaluate how policy action and intensification of irrigation in the São Francisco River Basin propagates downstream. This cascading downstream is evaluated in terms of the increased risk to downstream agricultural users who may face reduced or unreliable inflows in the river. Changes in the average flows or in its variability affect not only the management of downstream irrigation polygons, leaving downstream farmers more exposed to water shortages, but also may have significant impacts on other economic sectors such as fishery or hydropower production.

\section{Materials and methods}

\subsection{Database and representation of the basin}

Discharge data is available from the DSS522.1 dataset (DE/FIH/ GRDC and UNESCO/IHP, 2001) for 15 locations with record lengths ranging from 132 (Petrolandia) to 588 (Bom Jesus da Lapa) monthly average discharge records for the period January 1951 to December 1999 (600 months in total). Those points are used to divide the entire basin into 15 watersheds for which the outflow is known (Fig. 1) plus an extra watershed defined by the Três Marias dam for which the outflow has been deduced as a closure term of the mass balance calculated using the known outflows at the immediately downstream and upstream catchments. The discharge from the mouth of the São Francisco River Basin is ungauged though it is unlikely to differ much from the upstream gauge at Traipu given its closeness to the mouth. Also, for each of those watersheds, monthly data on precipitation and evapotranspiration is available from the CRU_TS_2.10 dataset (Mitchell and Jones, 2005) with a complete record for the period January 1951December 1999.

The Três Marias and Juazeiro watersheds are defined by the Três Marias and Sobradinho dams, which form two of the major reservoirs in the basin. Those are the only two dams considered in the model. Três Marias is a hydropower and flood control dam, completed in 1961. The dam has a maximum operational volume of $19.53 \mathrm{~km}^{3}$ at $572.5 \mathrm{~m}$ above mean sea level (amsl) with a planar

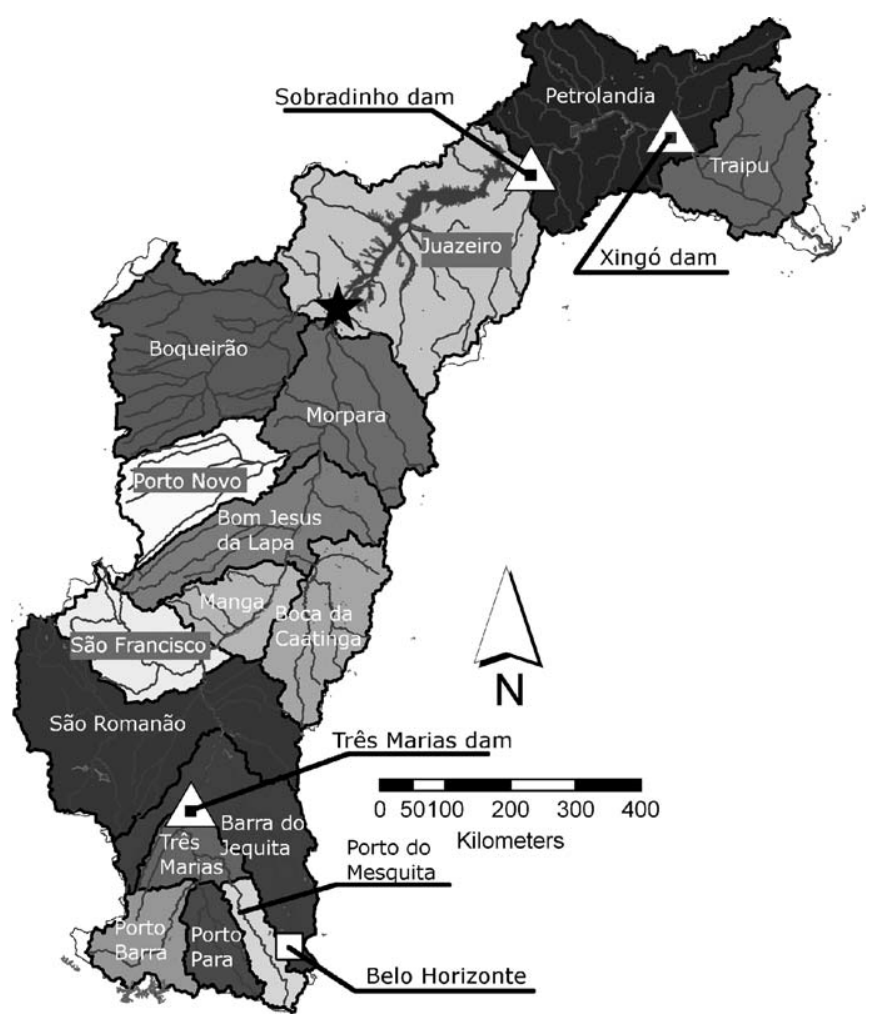

Fig. 1. The São Francisco River Basin showing the 16 watersheds in which it has been divided. The star indicates the confluence of the Rio Grande River with the São Francisco River, which is used in this paper as a check point to evaluate changes in river flows derived from increased agricultural activity in upstream areas. The watersheds are named after their gauging stations. Dams and towns mentioned in the text are labeled.

area of $1142 \mathrm{~km}^{2}$. The minimum operational level is at $549.2 \mathrm{~m}$ amsl having a volume of $4.25 \mathrm{~km}^{3}$ and an estimated area of $248.5 \mathrm{~km}^{2}$. The dam crest is set at $573.4 \mathrm{~m}$ amsl. The Sobradinho dam, finished in 1979, has a volume of $34.16 \mathrm{~km}^{3}$ and an area of $4214 \mathrm{~km}^{2}$ at its maximum operational level of $392.5 \mathrm{~m}$ amsl. The minimum operational level is considered to be at $380.5 \mathrm{~m}$ amsl holding $5.45 \mathrm{~km}^{3}$ with an area of $672.8 \mathrm{~km}^{2}$. The dam crest is set at $393.5 \mathrm{~m}$ amsl. In both cases a linear water level-water volume relationship and a linear water level-flooded area relationship have been used to characterize the reservoirs. The minimum regulatory flow under normal operations has been set to $1500 \mathrm{~m}^{3} \mathrm{~s}^{-1}$ (approximated from observed downstream flows).

No strong trend in the average precipitation or evapotranspiration or their variability was found in the records for any of the watersheds. In the case of runoff, the construction of the dams had a large impact only during their construction and filling periods. For the Sobradinho dam, its effect is mostly noticeable in the discharge measured at the downstream gauge by an increase in the minimum flows (to over $2000 \mathrm{~m}^{3} \mathrm{~s}^{-1}$ ) caused by the regulatory effect of the dam (Fig. 2). From 1987 to 1994, when the Xingó dam was built, the Sobradinho dam ensured flow to the hydropower complexes located downstream (Petrolandia). From this period on there is a more aggressive regulatory activity and the minimum mandatory flows are reduced to about $1800 \mathrm{~m}^{3} \mathrm{~s}^{-1}$.

Increased water uses included in this research comprise the projected expansions in the six developments upstream of the Sobradinho dam. Those developments are denominated Norte Minas, Guanambi, Formoso/Correntina, Barreiras, Irece and Juazeiro/Petrolina (Fig. 3). The projected irrigation districts and additional simulated irrigated areas are shown in Table 1 . The considered expansions are those either under study or currently 


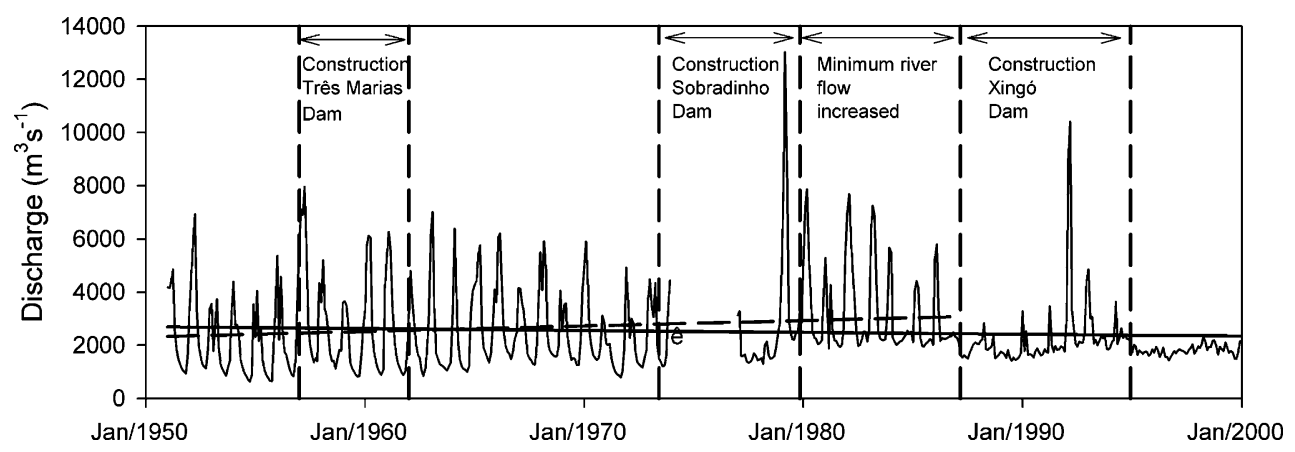

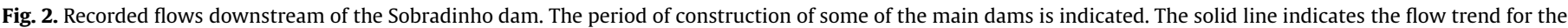
entire period 1950-2000. The dashed line indicates the trend for the period Jan 1950-1987 when the Xingó dam was built.

under implementation (ANA/GEF/PNUMA/OEA, 2004). There is a wide range of products and land allocation between the different irrigation districts but in general in the wetter south part of the basin there are large portions allocated to soy beans, corn and banana while in the north part there are large areas dedicated to table grape, and other products such as sugar cane are becoming popular.

The crop mix used in the simulations and the cropping calendar was taken from the current practices and crops produced, not only allowing for ample allocation of fruits, but also expanding emerging products such as table grape and sugar cane, especially in the north regions. The assigned crop mix and allocated land for the expansions in Norte Minas and Guanambi are shown in Table 2. Table 3 shows the same for the expansions in Formoso/Correntina, Barreiras, Irece and Juazeiro/Petrolina. The values for crop coefficients were calculated following the recommended FAO methodology (Allen et al., 1998) but modified with the coefficients suggested by local experts from the local agency EMBRAPA for some crops.

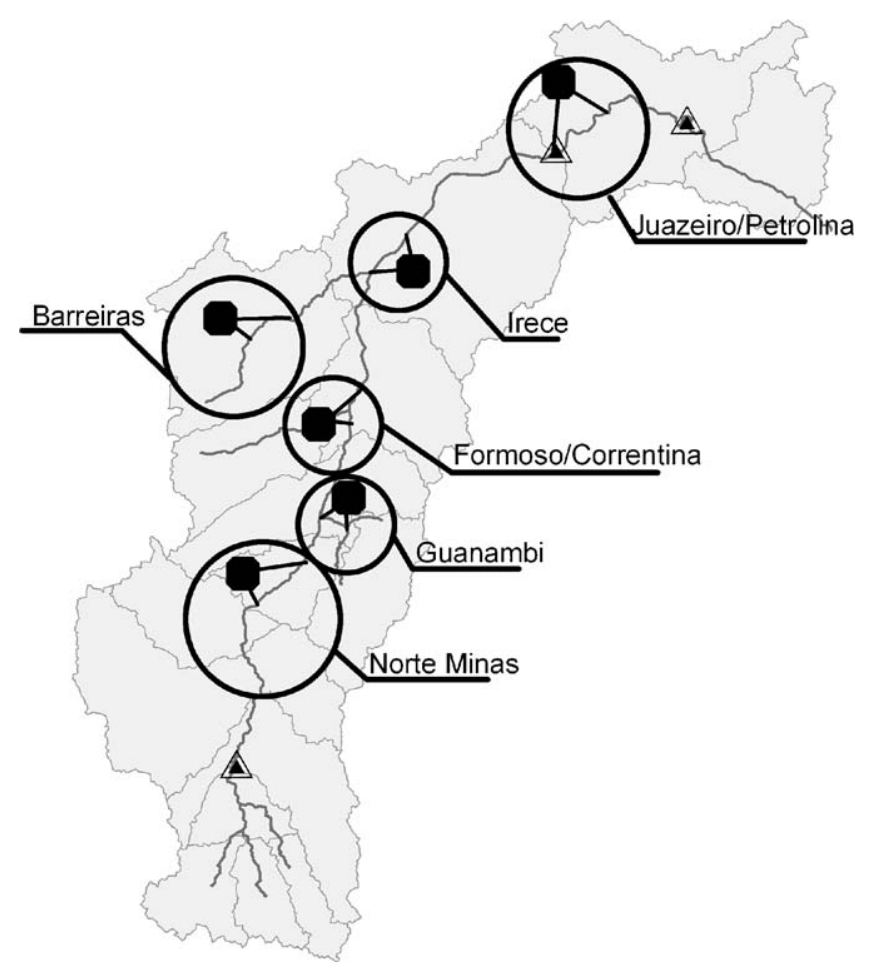

Fig. 3. Map showing the relative location of the irrigation developments. The black squares represent the expanded irrigation districts within the regions (enclosing circles) indicated in Table 1 . The lines are the water offtake and return channels. The basin is divided according to the 16 watersheds indicated in Fig. 1. Each of the six irrigation expansion is associated with a watershed from which it takes and to which it returns water.

\subsection{Study methods}

The water allocation and use in the São Francisco River was simulated using a conceptual semi-distributed modeling approach based on water accounting as implemented in MIKE Basin (Danish Hydraulic Institute, 2005). In this approach the basin is conceptualized as a set of interconnected elements that store, transfer or use water via catchments, channels, water users or reservoirs. The model solves the mass balance equation for each element at each time step given the supplied inflow and outflow information provided by the user. The inputs to each catchment are the sum of the outflows of the immediately upstream catchments. Individual contribution to river discharge by each catchment was calculated by subtracting the observed inflows (from the immediately upstream catchments) from the observed outflow. Outflows from reservoirs are controlled via release rules.

Because less than $5 \%$ of the water used for irrigation comes from groundwater sources (FAO, 2000), only water diversions from the surface system are considered. The discharge that gets diverted from the river to supply crop water needs is a function of crop water demand, precipitation and irrigation efficiency and is given by

$D W_{i p}=\max \left(0, \frac{E_{p} K c_{i p}-P_{p}}{I_{e f f}}\right) A_{i}$

The discharge diverted from the river to satisfy any crop $i$ at a given period $p D W_{i p}\left[\mathrm{~L}^{3} \mathrm{~T}^{-1}\right]$ is calculated as the crop water demand left unsatisfied by precipitation over the entire irrigated area allocated to crop $i$. This water deficit is modulated by an irrigation efficiency factor that accounts for inefficiencies in the system. Crop water demand is calculated as the reference potential evapotranspiration $E_{p}\left[\mathrm{LT}^{-1}\right]$ times a crop coefficient $K c_{i p}[-]$ associated to crop $i$ at period $p$ (Allen et al., 1998). $P_{p}\left[\mathrm{~L} \mathrm{~T}^{-1}\right]$ is precipitation at period $p ; I_{e f f_{i}}[-]$ is the irrigation efficiency factor for crop $i$ and $A_{i}$ $\left[\mathrm{L}^{2}\right]$ is the irrigated area dedicated to crop $i$. The function is truncated at zero by the max operator when precipitation is larger than crop water demand (no need for irrigation). When this happens, the second argument of the max function becomes negative and therefore the function returns to zero. The irrigation efficiency factor is bounded in the interval $0<I_{\text {eff }} \leq 1$, being unity for perfect efficiency (i.e. only the necessary water is diverted from the water source and applied to the crop). Lower $I_{\text {eff }}$ values account for inefficient irrigation technologies or water losses from pipes and channels. It is assumed that the water applied in excess will return to the river system in the form of runoff or subsurface flows except $10 \%$ of this water that is considered to be made available to the atmospheric demand and lost as evaporation. Given the time scale of the simulations, the model further assumes that soil storage does not change throughout the year.

The model, when run using the observed discharges, reflects the current water use situation in the basin taking into account all 
Table 1

\begin{tabular}{|c|c|c|c|}
\hline Development region & $\begin{array}{l}\text { Projected/expanded } \\
\text { irrigation districts }\end{array}$ & $\begin{array}{l}\text { Additional } \\
\text { area (ha) }\end{array}$ & $\begin{array}{l}\text { Total expanded area } \\
\text { per development (ha) }\end{array}$ \\
\hline Norte Minas & $\begin{array}{l}\text { Jaiba } \\
\text { Jequitaí } \\
\text { Rio das Velhas }\end{array}$ & $\begin{array}{l}40,276 \\
34,605 \\
25,000\end{array}$ & 99,881 \\
\hline Guanambi & $\begin{array}{l}\text { Vale do Iuiú } \\
\text { Estreito IV }\end{array}$ & $\begin{array}{r}88,306 \\
5,844\end{array}$ & 94,150 \\
\hline Formoso/Correntina & $\begin{array}{l}\text { Formoso 'H' } \\
\text { Correntina + Jaborandi }\end{array}$ & $\begin{array}{r}4,343 \\
164,000\end{array}$ & 168,343 \\
\hline Barreiras & $\begin{array}{l}\text { Barreiras Norte } \\
\text { Brejos da Barra }\end{array}$ & $\begin{array}{l}2,895 \\
4,300\end{array}$ & 7,195 \\
\hline Irece & Baixio do Irece & 58,659 & 58,659 \\
\hline Juazeiro/Petrolina & $\begin{array}{l}\text { Quixabeira, Paulo Afonso, } \\
\text { Brejos de Santa Maria, } \\
\text { Cruz das almas, } \\
\text { Ponta/Sobradinho } \\
\text { Salitre }\end{array}$ & 9,451 & 126,849 \\
\hline
\end{tabular}

current water uses and policies in place, thus providing a baseline to test potential water management or policy actions. Furthermore, it is assumed that implicit baseline hydrologic relationships between rainfall, runoff and river discharge remain unchanged. Any new water use is removed directly from the river system and the losses or inefficiencies by the water user are returned directly to the river. This impact is added to the baseline in which the actual water uses are embedded. In this work it is assumed that the change in land use derived from increasing the area dedicated to irrigated agriculture does not impact the rainfall-runoff relationship at the watershed scale, which is much larger than the projected land use change.

\subsection{Implementation}

The amount of supplemental water needed to irrigate crops depends on the amount of precipitation and the atmospheric demand for the period over which the crop grows. Because of the stochastic nature of the weather conditions, it is not possible to know in advance the exact amount of water needed to properly irrigate the crops. To deal with the stochastic nature of the problem, a Monte Carlo procedure is used to evaluate the impact that the increased amount of irrigated land will have on water diversions from the river and their effect on downstream flows. In this method, precipitation, reference evapotranspiration and runoff are treated as stochastic variables. A multitude of Monte Carlo runs produces an approximation of the frequency distribution for diverted water needed for irrigation and their effect on discharge rates in the river system. The simulation runs cover 1 year using monthly time steps.

A structural correlation between precipitation, evapotranspiration and runoff for each of the watersheds was expected. Typically, years with high monthly precipitation had high monthly runoff and lower monthly potential evapotranspiration. The covariance structure of the three variables provided information on that structural dependency. The available records do not show any trend in the mean or in the variability of precipitation or evapotranspiration, so the entire data set for each catchment was used to statistically characterize the climatic conditions. Regarding discharge, there are no strong trends in the flow data from the watersheds upstream of the Sobradinho dam, so the entire data record of each watershed is used to statistically characterize their flows. Also, since the regulatory effect of the Sobradinho dam is included in the model, the flow record prior to the year when the Sobradinho dam was built was used to characterize the downstream catchments.

For the sake of simplicity it is assumed that these hydrologic variables for each of the 16 watersheds in which the basin was

Table 2

Average monthly crop coefficients and crop mix in the expansions projected for Norte Minas and Guanambi.

\begin{tabular}{|c|c|c|c|c|c|c|c|c|}
\hline & Corn & Banana & Grapes & Sugar cane & Onions & Cotton & Beans dry & Tomatoes \\
\hline Jan & 0.8 & 1 & 0.6 & 1.2 & 1.3 & 1.15 & 0.35 & \\
\hline $\mathrm{Feb}$ & 1.1 & 1 & 0.8 & 1.2 & 1.2 & 1.11 & 0.4 & 0.6 \\
\hline March & 1.1 & 1 & 0.6 & 1.2 & 1.2 & 0.85 & 0.8 & 1 \\
\hline April & 0.6 & 1 & 0.9 & 1.2 & 0.95 & & 1.15 & 1.25 \\
\hline May & 0.5 & 1 & 0.5 & 0.8 & & & 0.35 & 1.25 \\
\hline June & 0.8 & 1 & 0.25 & 0.8 & & & & 0.7 \\
\hline July & 1.1 & 1 & 0.6 & 0.6 & & & & \\
\hline August & 1.1 & 1 & 0.8 & & & & & \\
\hline Sept & 0.6 & 1 & 0.6 & 0.5 & & & & \\
\hline Oct & & 1 & 0.9 & 1 & & 0.35 & 0.4 & \\
\hline Nov & & 1 & 0.5 & 1 & & 0.6 & 0.8 & \\
\hline Dec & 0.5 & 1 & 0.25 & 1.2 & 1.1 & 1.05 & 1.15 & \\
\hline Allocated land (ha) & 20.0 & 20.0 & 15.0 & 15.0 & 13.0 & 10.0 & 5.0 & 2.0 \\
\hline
\end{tabular}


Table 3

Average monthly crop coefficients and crop mix in the expansions projected for Formoso/Correntina, Barreiras, Irece and Juazeiro/Petrolina.

\begin{tabular}{|c|c|c|c|c|c|c|c|c|c|}
\hline & Soy & Corn & Banana & \multicolumn{2}{|c|}{ Beans dry } & \multicolumn{2}{|c|}{ Mango } & Rice & Onion \\
\hline Jan & 1.1 & 0.8 & 1 & 0.35 & & \multicolumn{2}{|c|}{0.8} & 1 & 1.3 \\
\hline $\mathrm{Feb}$ & 1.1 & 1.1 & 1 & 0.4 & & \multicolumn{2}{|c|}{0.8} & 0.75 & 1.2 \\
\hline March & 0.5 & 1.1 & 1 & 0.8 & & \multicolumn{2}{|c|}{0.8} & & 1.2 \\
\hline April & & 0.6 & 1 & 1.15 & & \multicolumn{2}{|c|}{0.8} & & 0.95 \\
\hline May & & 0.5 & 1 & 0.35 & & \multicolumn{2}{|l|}{0.4} & & \\
\hline June & & 0.8 & 1 & & & \multicolumn{2}{|l|}{0.44} & & \\
\hline July & & 1.1 & 1 & & & \multicolumn{2}{|l|}{0.65} & & \\
\hline August & & 1.1 & 1 & & & \multicolumn{2}{|l|}{0.83} & & \\
\hline Sept & & 0.6 & 1 & & & \multicolumn{2}{|l|}{0.83} & & \\
\hline Oct & & & 1 & 0.4 & & \multicolumn{2}{|l|}{0.84} & & \\
\hline Nov & 0.4 & & 1 & 0.8 & & 0.84 & & 0.5 & \\
\hline Dec & 0.8 & 0.5 & 1 & 1.15 & & 0.8 & & 0.8 & 1.1 \\
\hline \multirow{2}{*}{$\begin{array}{l}\text { Allocated } \\
\text { land (\%) }\end{array}$} & 24.3 & 15.4 & 16.0 & 12.8 & & 8.3 & & 3.8 & 3.2 \\
\hline & Tomato & \multicolumn{2}{|c|}{ Water melon } & Melon & \multicolumn{2}{|c|}{ Grapes } & \multicolumn{2}{|c|}{ Guava } & Sugarcane \\
\hline Jan & & \multicolumn{2}{|c|}{1.05} & & \multicolumn{2}{|l|}{0.6} & 0.7 & & 1.2 \\
\hline $\mathrm{Feb}$ & 0.6 & \multicolumn{2}{|c|}{1.05} & 0.6 & 0.8 & & 0.7 & & 1.2 \\
\hline March & 1 & 0.7 & & 0.8 & 0.6 & & 0.7 & & 1.2 \\
\hline April & 1.25 & & & 1.05 & 0.9 & & 0.25 & & 1.2 \\
\hline May & 1.25 & & & 1.05 & 0.5 & & 0.7 & & 0.8 \\
\hline June & 0.7 & & & 0.8 & 0.25 & & 0.7 & & 0.8 \\
\hline July & & & & 0.8 & 0.6 & & 0.7 & & 0.6 \\
\hline August & & & & & 0.8 & & 0.7 & & \\
\hline Sept & & & & & 0.6 & & 0.7 & & 0.5 \\
\hline Oct & & & & & 0.9 & & 0.7 & & 1 \\
\hline Nov & & 0.5 & & & 0.5 & & 0.7 & & 1 \\
\hline Dec & & 0.8 & & & 0.25 & & 0.7 & & 1.2 \\
\hline $\begin{array}{l}\text { Allocated } \\
\text { land (\%) }\end{array}$ & 3.2 & 2.9 & & 2.9 & 2.9 & & 2.9 & & 1.3 \\
\hline
\end{tabular}

divided could be hydrologically described by a multinormal probability density function defined by the mean and the covariance matrix obtained from the database of precipitation, potential evapotranspiration and runoff obtained from discharge.
No spatial (inter-watershed) correlation between the variables and no temporal autocorrelation was considered.

A Visual Basic script was used to implement the Monte Carlo procedure using the programming interface that permits running the Mike Basin engine externally. During each time step, a realization of the stochastic variables for each watershed is produced using its associated probability density function. For each of the projected irrigation polygons, Eq. (1) is applied to calculate the amount of diverted water needed to satisfy irrigation in the expanded area and the model is run for the current month (time step). An irrigation efficiency of 0.75 is assumed for all crops at all times from which $10 \%$ is lost and the remainder returned to the river system.

\section{Results and discussion}

The discharge at any point in the basin reflects the integrated effect of all the different water uses and upstream climatic regions. The southern and western part of the basin has a climate that can be classified as tropical with a dry season in the central months of the year (Fig. 4). In general, the difference between dry and wet season increases in wetter areas to the south and west. The most unpredictable month is March, which typically shows a large standard deviation. In general, the expected variability in rainfall is proportional to the average, so months with a large mean precipitation tend to be the most 'non-typical' months yielding precipitation amounts well above or below the long-term average. Furthermore, the variability in monthly precipitation is typically larger for the areas with semiarid and oceanic climates than for the south or western part of the basin. Conversely, the dry months are the most reliable. In those months little precipitation is expected and a year where the amount of precipitation is much larger than expected is very unlikely. In the central north and northeast parts the amount of precipitation is much lower while the atmospheric demand is high and quite constant throughout the year.

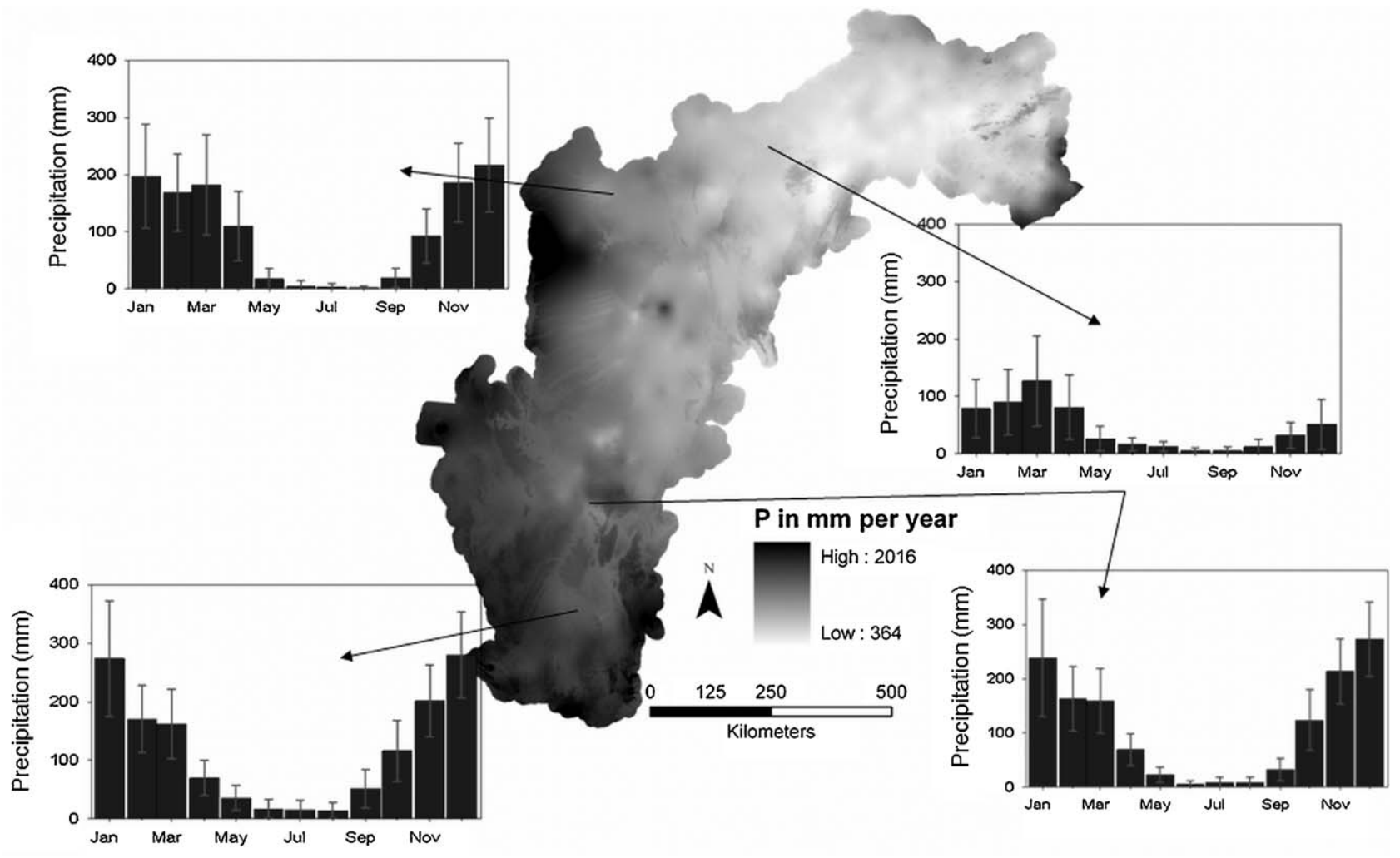

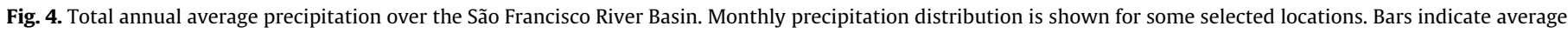
monthly precipitation. Whiskers indicate standard deviations. 

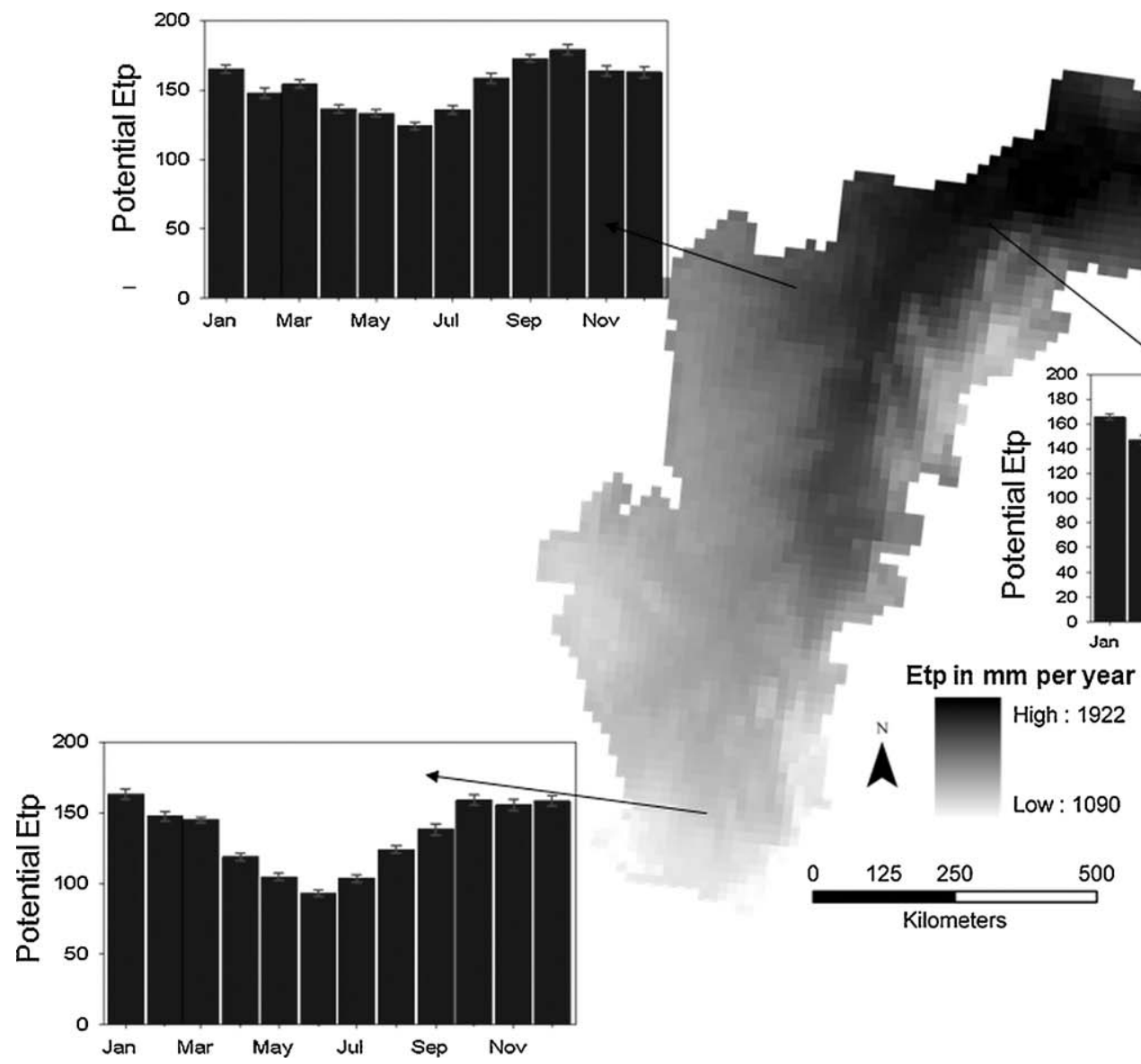

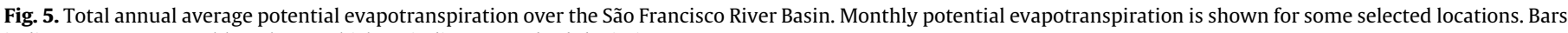
indicate average monthly values. Whiskers indicate standard deviations.

While the precipitation regime varies seasonally and spatially for different parts of the basin, the evapotranspiration pattern is more stable (Fig. 5). The evapotranspiration demand is high for all months but lower during the winter, although the oscillation is smaller compared to that of the precipitation. The south shows more contrasting evapotranspiration demand between winter and summer. Evapotranspiration has a very robust behavior, showing little variability around the mean value for each month.

The large climatic and physiographic contrast within the basin produces large variations in the water available to farmers. Where precipitation is not available or reliable, agriculture is only successful if there is irrigation infrastructure in place. Even when the infrastructure exists a spatial pattern in the variability of agricultural production and agricultural income can still be observed in the basin (Maneta et al., 2009). Water availability in the São Francisco River is defined by the São Francisco River Basin Commission as the discharge with a $95 \%$ of probability of being surpassed in a given year $\left(Q_{95}\right)$, which is the discharge beyond the 0.05 percentile of the distribution. For the case of regulated reaches, water availability is defined as the regulated discharge plus the $Q_{95}$ of the incremental discharge downstream of the regulated point (Braga and Lotufo, 2008). This definition of available water provides a safe discharge to satisfy multiple consumptive uses, including urban and industrial water needs or irrigation without compromising the ecosystem or other nonconsumptive activities such as hydropower generation, fishery or navigation needs. For the reference years of 2000-2003, the average water demand from the São Francisco River was between 138 and $168 \mathrm{~m}^{3} \mathrm{~s}^{-1}$ (about $68 \%$ of the water demand in the region), far from the $380 \mathrm{~m}^{3} \mathrm{~s}^{-1}$ theoretical limit of allocable water for consumption (ANA/GEF/PNUMA/OEA, 2004; Braga and Lotufo, 2008). Given the spatial and temporal variation of the water resources within the basin, water is still a limiting factor for irrigation expansion in some regions of the basin.

A limited amount of available water also poses a trade-off between strategic water uses. Irrigated agriculture and hydropower generation are direct competitors and make integrated water management of the basin necessary. Agriculture and the expansion of irrigated land have been used as a means to develop traditionally poor areas of the basin, especially in the semiarid northeast. The successful creation of pilot developments such as Barreiras or the region of Juazeiro/Petrolina and the increasing investments in fruits for export, sugar cane, soy beans and grapes and the interest in the production of bio-fuels promotes the expansion of irrigated agriculture beyond the existing 350,000 ha in 2003. Unfortunately, this will impact the water allocation in areas downstream of the diversion point affecting the amount of water that can be diverted to other irrigation polygons and may reduce the amount of water available for hydropower. The related reduction in hydropower generation may come just as the demands for energy increase.

Fig. 6 shows the result of the 500 Monte Carlo simulations of the diverted water to meet crop water demands in the six expansions according to the planting calendars and areas proposed in Tables 2 and 3. In general the largest average demand for water is concentrated in the dry months (May-September) and drops during the wet season (October-December). The demand in January-May is variable because rainfall variability in those months is the highest. These are also months where most of the irrigable area is cropped and at its highest water demand, to take 

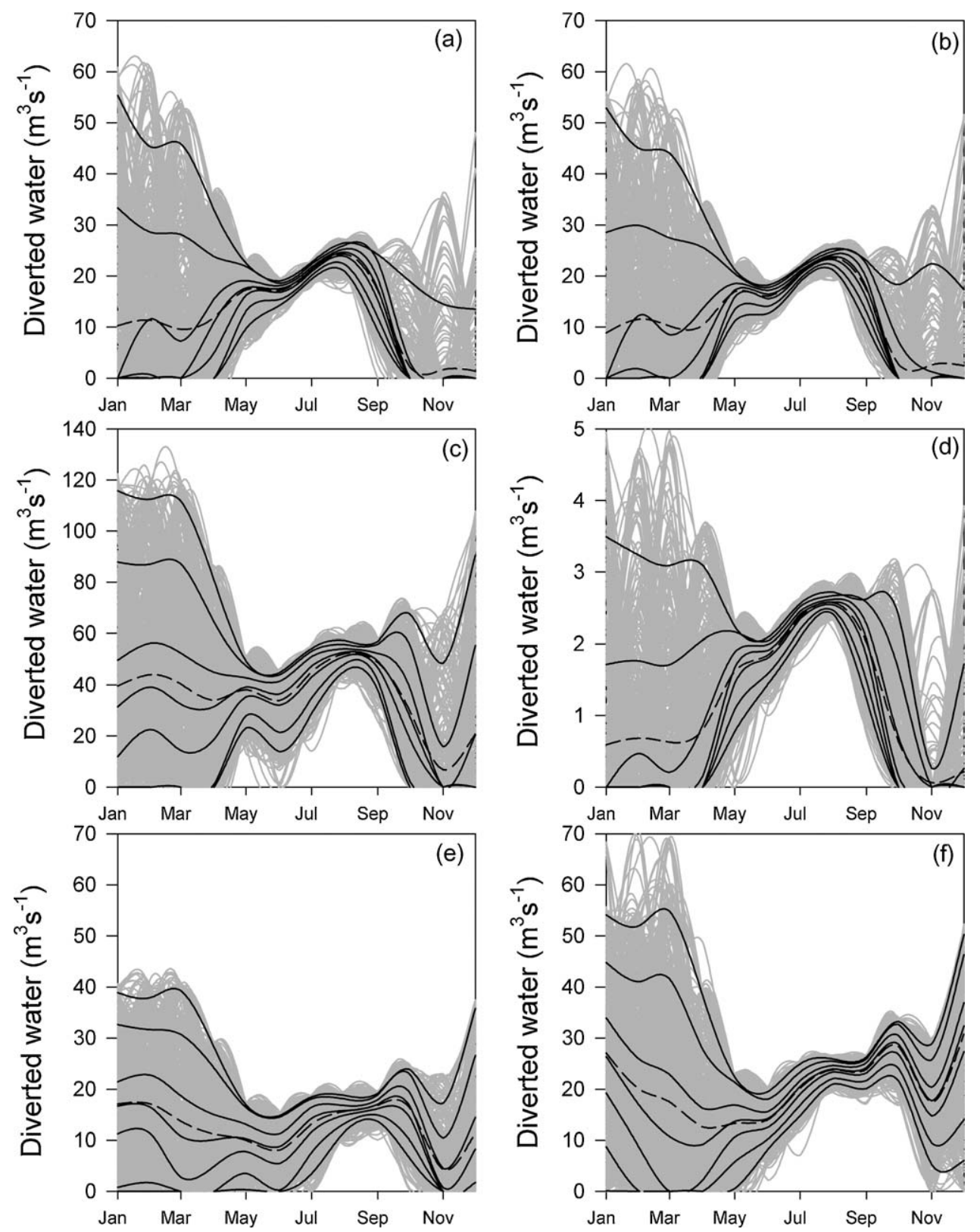

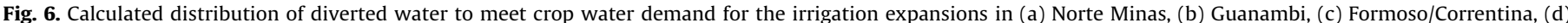

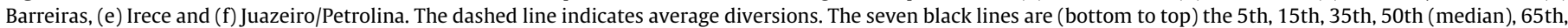
85 th and 95 th percentiles.

advantage of the seasonal rainfall. Because the irrigated area during those months is the largest, the average amount of water diverted for irrigation is in some cases larger or similar to the average amount of water diverted during the dry months. In terms of the frequency distribution of diverted water as obtained from the 500 simulations, the irrigation developments in the drier northern area of the basin (Formoso/Correntina, Irece and Juazeiro/Petrolina) approximate a normal distribution. In that case the median value of diverted water closely follows the average value. On the other hand, in the wetter southern developments of Norte Minas, Guanambi and Barreiras, water requirements and hence water diversions are positively skewed, so the median of the distribution is well below the calculated average crop water requirement. Thus, although the range of possible crop water needs is large in all developments, the expansions in the southern wetter areas of the basin have the most frequent water requirement concentrated in the low values as opposed to the more uncertain requirements that characterize the expansions in the drier northern half of the basin. It should be noted that the analysis does not include spatial and temporal autocorrelation of precipitation and evapotranspiration and, consequently, month to month values fluctuate more because they are not conditioned by the values at the previous time step or adjacent areas, thus the simulations present a conservative scenario for water requirements.

The large variability of rainfall during the first 3 months of the year together with the large areas cropped increases the risk of needing large amounts of water for irrigation. In the case of Norte Minas and Guanambi (Fig. 6(a) and (b)), 50\% of the years (median) will require less than about $10 \mathrm{~m}^{3} \mathrm{~s}^{-1}$ of water in the period January through March but $15 \%$ of the years will require more than $30 \mathrm{~m}^{3} \mathrm{~s}^{-1}$ and $5 \%$ of the years will have demands beyond $45 \mathrm{~m}^{3} \mathrm{~s}^{-1}$. In the case of Minas, the total projected deliverable water for two of the largest expansions sums to $99.7 \mathrm{~m}^{3} \mathrm{~s}^{-1}$ (ANA/ 
GEF/PNUMA/OEA, 2004), enough to satisfy the total needs of the agricultural expansion. In the case of Guanambi, the largest projected expansions (Estreito IV and Iuiú) sum to a total maximum capacity of $33.8 \mathrm{~m}^{3} \mathrm{~s}^{-1}$ (ANA/GEF/PNUMA/OEA, 2004).

In the case of the largest expansion, Formoso/Correntina (Fig. 6(c)), because of the large variability of monthly rainfall in the region, the range of possible water needs is large compared to the other expansions. Even though the distribution of water needs during the dry months is narrower, it is still relatively large compared to the other irrigation districts. From January to April the possible irrigation needs show the widest range, with the necessary diverted water at the 95 percentile of more than twice the average demand. The projected expansion in Barreiras is the smallest (Fig. 6(d)) and most consistent compared to the other projects. Average irrigation requirements in the dry months are about four fold greater than in the wet months. Crop demands are between 2 and $2.8 \mathrm{~m}^{3} \mathrm{~s}^{-1}$ from the end of May until September and only in 1 out of 20 years there may be need to irrigate more than $2.5 \mathrm{~m}^{3} \mathrm{~s}^{-1}$ in the period of January through April. The actual projected capacity for the irrigation subproject of Barreiras Norte, which accounts for about $40 \%$ of the total expanded irrigation area in Barreiras (Table 1) is $3.51 \mathrm{~m}^{3} \mathrm{~s}^{-1}$ (ANA/GEF/PNUMA/OEA, 2004).

The two developments farther north (Irece and Juazeiro/ Petrolina) and closer to the semiarid region are characterized by having lower and variable monthly precipitation. In the case of Irece (Fig. 6(e)) average irrigation requirements range from 10 to $20 \mathrm{~m}^{3} \mathrm{~s}^{-1}$ most of the year. While during the dry months water requirements (95 percentile line) are within this range, during the wet season there is about a 50\% chance that the amount of water to satisfy irrigation will be larger than the expected water required for irrigation during the dry season. The water delivery capability projected for the expansion of irrigation in this development is $63 \mathrm{~m}^{3} \mathrm{~s}^{-1}$. For the expansion in Juazeiro/ Petrolina (Fig. 6(f)), irrigation requirements during the dry season are slightly over $20 \mathrm{~m}^{3} \mathrm{~s}^{-1}$, which is about the same average amount required in January, February and December. In that case, as in the previous case, half of the years the irrigation requirements during the wet season may be larger than those expected in the dry season. The projected diversions from the river for this region, which presents the highest temperatures and lowest values for annual precipitation in the country, are about $140 \mathrm{~m}^{3} \mathrm{~s}^{-1}$ (ANA/GEF/PNUMA/OEA, 2004).

The average calculated water diversions to satisfy agricultural demands in all the expansions peaks at $142 \mathrm{~m}^{3} \mathrm{~s}^{-1}$ in August. The São Francisco River Commission estimates that the basin can use a total of $330 \mathrm{~m}^{3} \mathrm{~s}^{-1}$ for consumptive use to be split between current $\left(90.9 \mathrm{~m}^{3} \mathrm{~s}^{-1}\right)$ and projected demands before affecting hydropower production (Braga and Lotufo, 2008). This leaves about $239.8 \mathrm{~m}^{3} \mathrm{~s}^{-1}$ for future use, which is enough to cover the average water demands of the simulated irrigation expansions but may cause problems in case of a generalized drought. To be safe in $95 \%$ of the years the system should be able to support an extra demand peak of $320 \mathrm{~m}^{3} \mathrm{~s}^{-1}$ in January.

The projected irrigation expansions have an effect on the river flows. Figs. 7 and 8 show the simulated distribution of flows at the junction of the Rio Grande with the São Francisco River (check point in Fig. 1) and at Traipu near the basin outlet after running 500 Monte Carlo runs taking into account the extra demand. Despite the human impacts on the river system, the observed discharge pattern is still largely determined by precipitation and its variability. January through April are the months with largest river discharge, in synchrony with precipitation. Similarly, the months with highest discharge are the months that show larger variability. The most predictable monthly discharge occurs during the winter (dry) months, when discharge is lowest. In general, the monthly pattern shows the integrated effect of the climates of the

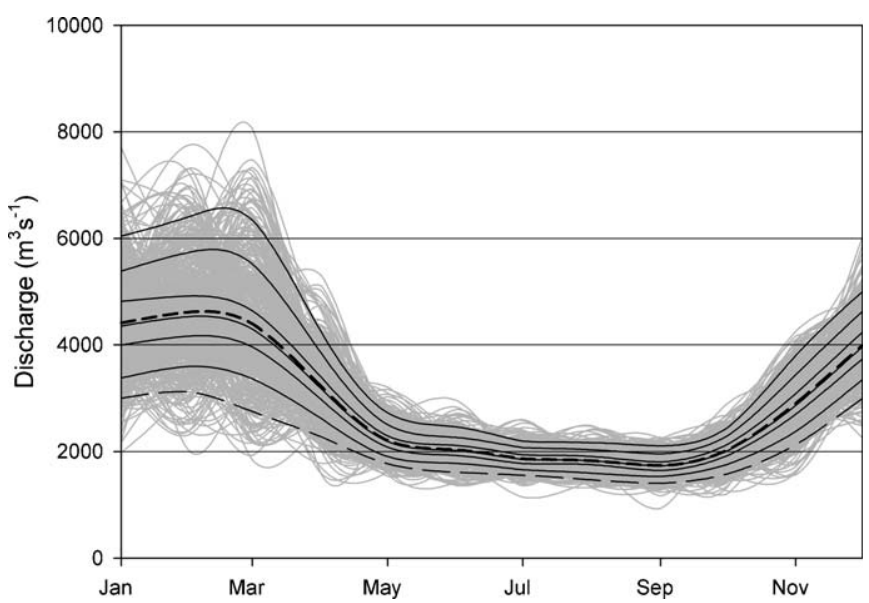

Fig. 7. Distribution of flows at the junction of Rio Grande with the São Francisco River from 500 Monte Carlo simulations of the irrigation expansion scenario. The thick dashed line indicates the average flow. The thin dashed line is the 5th percentile or the discharge with a $95 \%$ of probability of being surpassed any given year $\left(Q_{95}\right)$. The other black lines are the 15th, 35th, 50th (median), 65th, 85th and 95th percentiles.

basin and in the case of flows in the lower reaches of the São Francisco River it shows the regulating effect of the multiple reservoirs. The high evapotranspiration values and low precipitation in the semiarid north contributes little local discharge to the river flow especially during the driest months. Because of this, the flows observed at the gauging stations downstream of the Sobradinho dam are dominated by the release rules of the reservoir. In fact, from May through September, the simulated flows at the basin outlet converge, with little variation about the minimum release flows.

The impact that increased agricultural activity has on the inflows to the Sobradinho dam can be seen in Table 4 for the checkpoint at the confluence of the São Francisco River with the Rio Grande (Fig. 1). The most direct impact is on the reduction of the average flows, of more than $90 \mathrm{~m}^{3} \mathrm{~s}^{-1}$ from the baseline to the expansion scenario, during the dry months. The minimum average flow occurring in September decreases from 1828.6 to $1735.7 \mathrm{~m}^{3} \mathrm{~s}^{-1}$. A decrease in average flows in January, February and March is also important because during those months the total cropped area is the largest. The most obvious impact of the increased irrigated

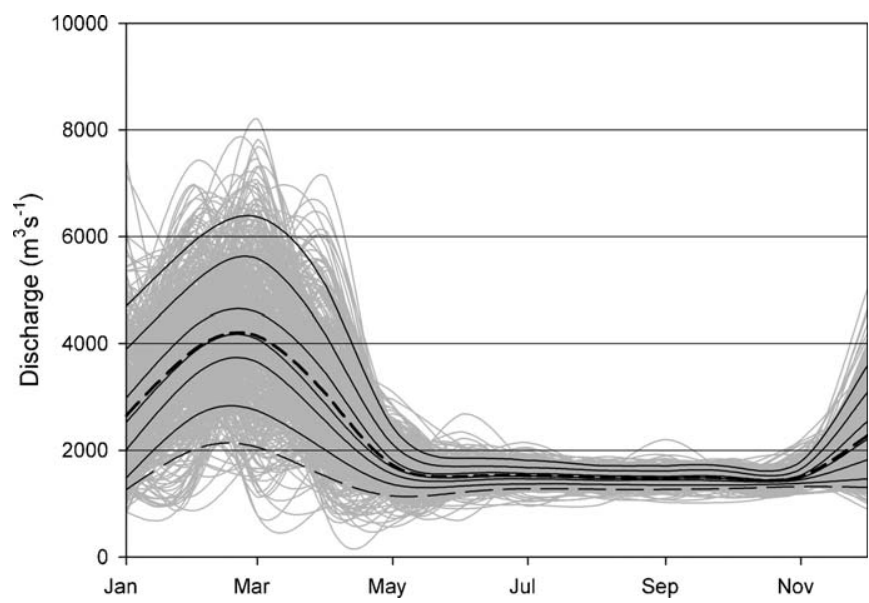

Fig. 8. Distribution of flows near the outlet at Traipu from 500 Monte Carlo simulations of the irrigation expansion scenario. The thick dashed line indicates the average flow. The thin dashed line is the 5 th percentile or the discharge with a $95 \%$ of probability of being surpassed any given year $\left(Q_{95}\right)$. The other black lines are the 15th, 35th, 50th (median), 65th, 85th and 95th percentiles. 
Table 4

Average, $Q_{95}$ (5th percentile) and difference in discharge for the baseline and irrigation expansion scenario at the confluence of Rio Grande with the São Francisco River.

\begin{tabular}{|c|c|c|c|c|c|c|c|}
\hline & & Jan & Feb & Mar & Apr & May & June \\
\hline \multirow[t]{3}{*}{ Average } & Baseline & 4517.1 & 4740.4 & 4475.1 & 3274.7 & 2303.7 & 2101.5 \\
\hline & Scenario & 4414.4 & 4618.2 & 4396.1 & 3225.2 & 2207.3 & 2028.6 \\
\hline & Diff & -102.7 & -122.2 & -79.0 & -49.5 & -96.4 & -72.9 \\
\hline \multirow[t]{4}{*}{$Q_{95}$} & Baseline & 2919.0 & 3136.3 & 2865.9 & 2402.3 & 1905.8 & 1718.5 \\
\hline & Scenario & 3001.1 & 3113.8 & 2750.7 & 2276.2 & 1768.8 & 1608.7 \\
\hline & Diff & 82.0 & -22.5 & -115.2 & -126.1 & -137.0 & -109.8 \\
\hline & & July & Aug & Sep & Oct & Nov & Dec \\
\hline \multirow[t]{3}{*}{ Average } & Baseline & 1982.2 & 1938.0 & 1828.6 & 2068.3 & 2921.8 & 4050.2 \\
\hline & Scenario & 1861.8 & 1824.2 & 1735.7 & 2025.9 & 2904.7 & 3994.4 \\
\hline & Diff & -120.3 & -113.8 & -92.9 & -42.5 & -17.0 & -55.7 \\
\hline \multirow[t]{3}{*}{$Q_{95}$} & Baseline & 1613.2 & 1612.5 & 1511.6 & 1596.1 & 2141.5 & 3093.7 \\
\hline & Scenario & 1550.6 & 1465.5 & 1404.5 & 1579.9 & 2131.0 & 2996.5 \\
\hline & Diff & -62.7 & -147.0 & -107.1 & -16.2 & -10.5 & -97.3 \\
\hline
\end{tabular}

Table 5

Average, $Q_{95}$ (5th percentile) and difference in discharge for the baseline and irrigation expansion scenario at Traipu near the basin outlet.

\begin{tabular}{|c|c|c|c|c|c|c|c|}
\hline & & Jan & Feb & Mar & Apr & May & June \\
\hline \multirow[t]{3}{*}{ Average } & Baseline & 3160.2 & 3976.6 & 3996.7 & 3160.0 & 1753.3 & 1516.2 \\
\hline & Scenario & 2655.7 & 3903.6 & 4142.8 & 3054.9 & 1721.2 & 1511.7 \\
\hline & Diff & -504.6 & -73.0 & 146.1 & -105.1 & -32.0 & -4.5 \\
\hline \multirow[t]{4}{*}{$Q_{95}$} & Baseline & 1395.2 & 2258.5 & 2021.0 & 1549.7 & 1175.6 & 1171.4 \\
\hline & Scenario & 1266.9 & 2025.1 & 2057.2 & 1509.2 & 1142.5 & 1213.8 \\
\hline & Diff & -128.3 & -233.4 & 36.2 & -40.4 & -33.1 & 42.3 \\
\hline & & July & Aug & Sep & Oct & Nov & Dec \\
\hline \multirow[t]{3}{*}{ Average } & Baseline & 1524.7 & 1483.0 & 1475.5 & 1469.5 & 1566.1 & 2628.3 \\
\hline & Scenario & 1519.8 & 1485.1 & 1480.7 & 1469.0 & 1514.3 & 2280.9 \\
\hline & Diff & -4.9 & 2.1 & 5.3 & -0.5 & -51.8 & -347.3 \\
\hline \multirow[t]{3}{*}{$Q_{95}$} & Baseline & 1264.8 & 1283.3 & 1259.7 & 1286.2 & 1301.0 & 1426.9 \\
\hline & Scenario & 1278.7 & 1268.9 & 1268.1 & 1284.5 & 1319.4 & 1305.7 \\
\hline & Diff & 13.9 & -14.4 & 8.4 & -1.7 & 18.4 & -121.2 \\
\hline
\end{tabular}

agriculture is a general downward shift of flows but there is also some increase in flow variability because the simulated extremes of the distribution tend to vary more than the simulated average flows in the period from March through September.

The river flows at the outlet (Table 5) are also affected but unlike upstream of the Sobradinho reservoir, the regulating effect of the dam strongly alters the flow distribution and limits the minimum released downstream flows. During the dry months, especially August through October, the regulated minimum flows are just met and the average flows vary little between the baseline and the expanded agriculture scenario. During the wet months from November through February, because of the reduced inflows to the Sobradinho reservoir and the diversion from the large expansion of Petrolina/Juazeiro, downstream water releases are strongly reduced. On average, but especially during dry years, seepage reduces flow in the lower reaches of the São Francisco River downstream of Sobradinho. Because of this, discharge at Traipu is sometimes smaller than the minimum regulated downstream water release during dry years. It is worth noting that during dry months when both the baseline and the scenario converge to minimum mandatory releases, the calculated discharge for the simulated scenario is slightly larger than the baseline because of increased downstream water returns from increased irrigation. Average flow differences are larger than differences for the $Q_{95}$ because during dry years both baseline and scenario flows are low. Flow reductions are larger during the wet months to increase storage and because during dry months the dam releases are required to maintain minimal flows (although at the expenses of decreasing storage). Also, during years of precipitation shortfalls, the large upstream cropped areas under irrigation from November through March demand a large amount of water and decrease inflows to the reservoir. Yet, the impact on flows in the lower reaches of the river is only marginal even when all downstream water uses are guaranteed because the dam releases are available.

The simulations show that water availability in the river system is not limiting even in the scenario of expanded agriculture. Therefore most of the problems reported in irrigated agriculture seem to be related to lack of delivery capacity from the river to the irrigation developments and/or to slower than expected irrigation development. A recent report by the Brazilian Government (Brazilian Court of Audit, 2003) shows that the income per irrigable hectare in year 2000 was low due to lack of available water and the presence of large idle areas. Those idle areas have a strong negative impact because the infrastructure for those areas is constructed and the investment computed even though the area is not producing (Brazilian Court of Audit, 2003). According to this study, in the year 2000 , the irrigation perimeters managed by the São Francisco River Development Agency (CODEVASF) and the National Drought Prevention Works Department (DNOCS) had 52,025 idle hectares corresponding to an investment of $\$ 840$ million. For instance the Nilo Coelho irrigation district, located immediately downstream of the Sobradinho dam and one of the most productive perimeters in the São Francisco River Basin, has an area of 45,000 ha that can potentially be irrigated but only between 12,500 and 13,500 ha are actually irrigated. For this district, the maximum rate of water diverted at the pumps from the offtake point (Sobradinho reservoir) is $23.2 \mathrm{~m}^{3} \mathrm{~s}^{-1}$. The peak demand during droughts may potentially cause shortages during the months when the amount of cultivated area is the largest. The pattern of variability of irrigation requirements indicates that designing maximum water diversions based solely on the dry months having the largest average demand (when variability is low) may cause shortfalls during the wet season (when variability is high) in drought years.

\section{Summary and conclusions}

Increased irrigation in the São Francisco River Basin is a goal of the governmental development agency CODEVASF. But that expansion in a basin where water is used for multiple uses, some of which are strategic such as hydropower production, needs quantification for management planning.

This paper presented how six large projected expansions of irrigated land in different regions of the basin affect the allocation of water downstream. The research used a Monte Carlo procedure that made use of the known distribution of precipitation, potential evapotranspiration and river flows at the monthly scale to statistically characterize the behavior of 16 watersheds within the São Francisco River Basin. The six projected expansions and their associated water diversions to fulfill irrigation requirements as well as the resulting distribution of river flows were obtained using 500 Monte Carlo simulations.

The spatial and temporal variability of rainfall and atmospheric demand for the different regions of the basin make irrigation demands variable. Because rainfall is most variable during the rainy season and because at this time the cropped area is the largest, water demands for irrigation may be highest in the event of a dry year. During the dry season, because little rain is expected the area cropped is smaller, irrigation requirements are lower and more predictable. Because irrigation requirements during the wet season are often higher than for the dry season, irrigation allocations should take that into account to reduce the risk of 
irrigation shortfalls, particularly for dry years. Using this strategy, the proposed allocated water from the river system will meet the potential irrigation requirements in most cases. Furthermore, the results indicate that the proposed expansions, totaling an extra irrigated area of 555,077 ha can be accommodated without affecting downstream releases for hydropower. The sum of the expected extra diversions is about $142 \mathrm{~m}^{3} \mathrm{~s}^{-1}$ although peaks up to $320 \mathrm{~m}^{3} \mathrm{~s}^{-1}$ are expected during droughts.

Increased irrigation activity shifts downward the distribution of river flows, reducing the amount of inflow to the Sobradinho dam. The average flow is more than $90 \mathrm{~m}^{3} \mathrm{~s}^{-1}$ reduced during the three months with lowest discharge. In wet months, that reduction can increase to $122.2 \mathrm{~m}^{3} \mathrm{~s}^{-1}$ because cropped area is largest and rainfall may be much less than the average, requiring large quantities of supplemental irrigation. Also, the lowest flows expected in 1 out of 20 years will decrease from 1612 to $1465 \mathrm{~m}^{3} \mathrm{~s}^{-1}$. Downstream of the Sobradinho dam flow reductions are less pronounced during the dry season for dry years because the minimal downstream releases are regulated through the release of storage. Conversely during the wet season there is a reduction of the downstream flows of about $505 \mathrm{~m}^{3} \mathrm{~s}^{-1}$. The reductions are needed to keep storage at levels that ensure downstream releases during the dry season.

\section{Acknowledgements}

This research project is sponsored in part by the Challenge Program on Water and Food (CPWF) of the Consultative Group on International Agricultural Research (CGIAR), in collaboration with the International Water Management Institute (IWMI).

\section{References}

Allen, R.G., Pereira, L.S., Raes, D., Smith, M., 1998. Crop Evapotranspiration, Guidelines for Computing Crop Water Requirements. FAO Irrigation and Drainage Paper, 56. Food and Agriculture Organization of the United Nations, Rome, $300 \mathrm{pp}$.

ANA/GEF/PNUMA/OEA, 2004. Projeto de gerenciamiento integrado das atividades desenvolvidas em terra na bacia do Sao Francisco. Subprojeto 4.5C - Plano decenal de recursos hidricos da bacia hidrografica do Rio San Francisco - PBHSF (2004-2013). 12, Superintendência de Conservaçao de Água e Solo, Brazilia.

Braga, B.P.F., Lotufo, J.G., 2008. Integrated river basin plan in practice: the Sao Francisco River Basin. International Journal of Water Resources Development 24 (1), 37-60.

Brazilian Court of Audit, 2003. TCU evaluation of the irrigation and drainage program. In: TCU (Ed.), Government Programs Control and Evaluation Secretariat, pp. 14.

CODEVASF, 1994. CODEVASF - 20 anos de sucesso. Montes Claros: Arruda Vídeo e Produções, Brasilia.

CODEVASF, 1996. Programa de desenvolvimento sustentável da Bacia do Sao Francisco e do semi-árido nordestino. Sintese, CODEVASF, Brasilia.

Danish Hydraulic Institute, 2005. MIKE Basin 2005. User's Guide.

DE/FIH/GRDC and UNESCO/IHP, 2001. Annotations for Monthly Discharge Data for World Rivers (excluding former Soviet Union). Published by the CISL Data Support Section at the National Center for Atmospheric Research [http://dss. ucar.edu/datasets/ds552.1/].

FAO, 2000. Aquastat, Information System on Water and Agriculture. Country Profile: Brazil. Food and Agriculture Organization, http://www.fao.org/nr/ water/aquastat/countries/brazil/index.stm.

Maneta, M., Singh, V.P., Torres, M., Vosti, S., Rodrigues, L., Bassoi, L., Young, J., 2009. Parsimonious crop water productivity index under unforced conditions for large basins. Area 41 (1), 94-106.

Mitchell, T.D., Jones, P.D., 2005. An improved method for constructing a database of monthly climate observations and associated high resolution grids. International Journal of Climatology 25, 693-712.

Romano, P.A., Cadavid Garcia, E.A., 1999. Policies for water-resources planning and management of the Sao Francisco River Basin. In: Biswas, A.k., Cordeiro, N.V. Tortajada, C., Braga, B.P.F. (Eds.), Management of Latin American River Basins: Amazon, Plata, and São Francisco. United Nations University Press, pp. 325 